\title{
IMPACT OF THE PANDEMIC ON RETAIL TRADE IN UKRAINE
}

\author{
Brzhozovskyi Tymofii \\ Master's degree student \\ of Faculty of Mechatronics and Computer Technologies \\ Kyiv National University of Technologies and Design, Ukraine \\ Gudkova Nataliia \\ PhD in Linguistics, Ass. Prof. of the Department of Philology and Translation \\ Kyiv National University of Technologies and Design, Ukraine
}

\begin{abstract}
Summary. The coronavirus pandemic has had a significant impact on all areas of society. The epidemiological environment has given much uncertainty to consumers and companies alike, resulting in adaptation to the new insular environment. This article examines the impact of the coronavirus pandemic on the retail industry. Emphasis is placed on how COVID-19 has influenced changes in assortment policy in the retail sector. The prevailing epidemiological situation led to increased prices. Moreover, due to the introduction of social distancing requirements, retail shop closures and recommendations for isolation measures to prevent the spread of the virus, consumers have been spending more time purchasing goods online, using contactless payment and receipt. The study also shows that the behavioural shift in consumer actions has predominantly occurred towards digital platforms and digital content, which has created real opportunities for brands to promote beauty products by targeting advertising messages to the audiences through new Internet marketing tools. With the rise in social media engagement and the desire for digital content, new opportunities have opened up for cosmetic retailers to help maintain communication with consumers even during a pandemic.
\end{abstract}

Keywords: Marketing mix, product, price, place, promotion, advertising, internet marketing, COVID19, pandemic.

Introduction. The coronavirus pandemic has had a significant impact on all areas of society. Due to the government's requirements for business continuity, food and convenience retailers such as supermarkets, pharmacies, and convenience stores (except office areas) are in good condition. Consumers line up to buy food at the checkout counter, many of which have been sold out. On the other hand, shopping for non-essential items such as clothing and electrical appliances and luxury goods retailers have stagnated.

Methodology. The paper involved the method of analysis, the systems analysis method, the comparative method, which are the methodological basis of the research.

Results. The rapid changes in the external environment caused by COVID-19 have had different effects on retail business. This crisis has created a sharp contrast between the performance of different types of companies. 
The focus on changes in retail business processes that are particularly affected by COVID-19 shows that in the area of food and fast-moving consumer goods retail, examples of operational measures include putting stickers on the floor to mark appropriate social distancing locations for customers waiting in line at the checkout. Vinyl curtains were also installed at the cash register, partly to protect employees. In addition, in response to customer demand for safety, activities such as disinfecting trolleys and individually packaging products to prevent droplet infection have been added to daily work, which has increased employee fatigue. Some people try to encourage shoppers to use e-commerce by placing orders online and picking them up in stores. The purpose is to disperse customer visits to the store, but the capacity of the pre-order system is too low to achieve the desired effect.

At the same time, the company headquarters had to take urgent measures to ensure business continuity in response to the sudden shift to remote work. They must implement changes, such as authorizing employees to use company computers at home and arranging for paper documents to be taken off-site. Another example is the rotation system they set up for employees. One of the characteristics of the retail business is that when the store is operating at full capacity, the headquarters that supports them cannot stop working, so they have to make major changes to their normal working methods. In addition, due to the inability to obtain a stable supply of products from business partners, the store had to propose new operations to solve the inventory problem, such as restricting certain products to one purchase per customer. As a result, business processes in all areas of the retail industry have felt the impact, and countermeasures have been taken for several months.

Not all retailers are affected by the restrictions. Grocery stores and convenience stores took advantage of the opportunity to increase their turnover and were prepared to get out of the epidemic without major losses. They used the following techniques. During the restrictive measures of the COVID 19 pandemic, the retail sector faces new challenges requiring unconventional, rapid, flexible and informed solutions. According to the Ministry of Industry and Trade of Ukraine, the decline in retail turnover in April 2020 amounted to 23.4\% year-on-year, in May it was over 19\%, in June almost 8\% [1]. Consumer preferences and behaviour of potential customers, financial capabilities, and purchasing methods - the main demand drivers - are changing. Such changes have exacerbated the need to make significant adjustments to assortment programmes, trading patterns and other organisational issues, and have set the path for a measured business transformation.

According to preliminary estimates from Statistics Cyprus, the main hit of the restrictive retail measures came in the sales of clothing, footwear and electrical goods. The sales turnover index fell in these sectors by 22.3-24.2\%, meaning that they lost the same $1 / 5$ of their annual turnover. On the other hand, food and beverage retail sales in non-specialised shops increased by $6.2 \%$ and in specialised shops by $5.7 \%$. In self-service shops specialising in building materials, furniture, household appliances, the index declined marginally (by $0.2 \%$ ), especially when you consider that from May to July there was a big increase (in May by $15 \%$, in June by $19.8 \%$, in July by $12.7 \%)$ [2]. 
Experts cite the «thirteenth wage» as the driving force behind consumer demand in December. However, in the private sector the payment of the New Year bonus to employees is highly questionable, especially where companies are still closed because of the pandemic. So the market has only to rely on spending by civil servants. They will be paid all their bonuses unchanged.

The problems facing the market were the subject of a message from the chairman of the Cyprus Chamber of Commerce and Industry (CCCl), Christodoulos Angastignotis, to Finance Minister Konstantinos Petridis. In it, he asks for consideration of additional subsidies for companies from the budget. He stated that the Christmas holiday period is one of the most profitable periods of the year for many retailers. Because of this, many of them pre-purchase necessary goods for sale from suppliers, spending thousands of euros on it. The fact that companies are mandatorily shutting down due to relevant government decrees significantly worsens their already strained financial situation. The risk that they will not recover from such a situation is quite palpable. It is clearly impossible for them to meet any current financial obligations other than paying salaries. He offered to implement generous targeted business subsidy programmes because he believes that the longer the announcement of new support measures is delayed, the greater the risk of companies closing down, with all the known consequences of this turn of events.

The retail industry is to respond to the challenge and some recommendations are given. It is necessary to take the following actions: 1) to revise the depth of assortment within a category in line with changing demand - for some categories this will mean reducing the number of stock keeping units and for some it will mean flourishing and increasing assortment items; 2) to build a price image based on new categories - the increased rotation of some categories means that they are «on the radar» of consumers. The role of products and categories will change and this will have a significant impact on price perception; 3) to adapt the promotional policy consumers like promotions and it is difficult to move to an EDLP (every day low price) strategy at this time. However, many chains will continue to use the Hi-Lo strategy, which has the advantages of being both easy to use and accurate [3]. In the case of high unemployment, consumers will unfortunately have more time to choose the best offers from many shops. Changing consumer behaviour also requires changes in terms of promotion planning, with a focus on new, fast-growing categories. The use of Big Data tools, dynamic pricing and the creation of individual, special offers as part of a loyalty programme are, of course, big opportunities in this.

There are some challenges to generating additional margins in different formats and forecasts for the near term. Ongoing margin pressure is the simultaneous effect of two factors: 1) cost increases caused by inflation, weakening of national currencies, predicted drought (in the case of food). Only the recent fall in oil prices is a positive factor in this area. In addition, the COVID-19 pandemic means that chains must follow the recommendations of health authorities and increase operational costs (for gloves, food packaging, disinfectant fluids, employee masks); 2) pressure on price restrictions on trade and consumer movement cause a general drop in sales. Networks try to increase sales online - in a channel characterised by greater price transparency. It may come to price wars (using promotions) if networks decide that demand stimulation is only possible by lowering prices. 
In order to keep margins at a satisfactory level in such a situation, the significant changes in sales channels, price management, pricing mechanisms and promotions are needed [4]. They are the following:

1. a stronger bias towards directing the customer to shop through online channels [5];

2. the shift in importance of certain products and categories from the consumer's perspective is forcing networks to reassess their current margins and promotions plans. Only their adjustments will maintain a positive pricing image;

3. increasing the depth of promotions using old approaches may not produce the expected results in the long term (although in the short term, with the right approach, it will ensure that liquidity is maintained);

4. retaining existing customers through loyalty programmes and tailored offers $[6] ;$

5. consistently increasing the value proposition through enhanced customer experiences both online (extended return time, free shipping) and offline (hygiene and shopping security, product availability, reduced queues) [7].

The retail sector has suffered enough during the Coronavirus pandemic. Grocery retailers, on the other hand, have fared better than most other sectors in coping with the pandemic. One of Ukraine's largest retailers, METRO Cash \& Carry Ukraine, saw sales increase by 30\% during the quarantine period [8]. And this despite the fact that in the Hotel, Restaurant, Cafe segment, the key audience of the chain, demand has dropped. The growth was achieved due to new customers and reactivation of customers who did not visit METRO. It was the audience research and algorithms that helped bring people into shops.

During the pandemic, 22\% of Ukrainian retailers reported a 50\% increase in online sales. METRO saw the number of online orders double in the first half of 2020. During a severe lockdown in April, the growth was even threefold. The share of online trade in money terms grew not so significantly from March to July - from 3\% to 4.6\% of the total turnover. The retailer does not disclose exact amounts. $97 \%$ of online orders in B2C (Business-to-consumer)-segment provided a partnership with the service zakaz.ua. With it, METRO launched its online shop in 15 cities. Seven of them were added during the quarantine period [9]. But during the first weeks of the lockdown the retailer temporarily stopped advertising the online shopping - pickers and deliverers could not cope with the increasing load.

The most successful online promotion channel for METRO is contextual advertising. The chain was introduced to digital tools in 2015. The transition was abrupt, straight out of the Gutenberg era: before that, for 12 years, consumers had been contacted via paper catalogues. They were expensive to deliver, and they did not provide feedback [10].

Conclusions. To sum up, the COVID-19 pandemic had drastic effects on economic activity in transportation. The new reality does not mean a reduction in the product range and a concentration on low-price products only. It means a qualitative change resulting from a new consumer approach to reality, which forces chains to comprehensively rethink their pricing and assortment policies. The strategy has to be adapted to the new market realities. 


\section{References:}

[1] Ukrainian food and beverages industry. URL: file:///C:/Users/DELL/Downloads/UKRAINIAN-FOOD-BEVERAGES-INDUSTRY2020\%20(1).pdf

[2] Cyprus Retail Sales YoY. Trading Economics. URL: https://tradingeconomics.com/cyprus/retail-sales-annual

[3] Hi-Lo Card Counting System. Online Blackjack for Real Money. URL: https://www.onlineblackjackrealmoney.org/card-counting/hi-lo

[4] Kort P. M., Taboubi S. \& Zaccour G. Pricing decisions in marketing channels in the presence of optional contingent products. Central European Journal of Operations Research. 2020. № 28. P. 167-192. URL: https://doi.org/10.1007/s10100-018-0527-x

[5] Yonghui Raol, Aysha Saleem, Wizra Saeed and Junaid UI Haq. Online Consumer Satisfaction During COVID-19: Perspective of a Developing Country. Frontiers Psychology. 2021. URL: https://doi.org/10.3389/fpsyg.2021.751854

[6] Greg Kihlstrom. How Customer Loyalty Programs Can Enhance the Customer Experience. Forbes. 2018. https://www.forbes.com/sites/forbesagencycouncil/2018/11/20/how-customer-loyaltyprograms-can-enhance-the-customer-experience/?sh=237cce745a46

[7] McKinsey \& Company. Perspectives on retail and consumer goods. 2020. https://www.mckinsey.com/ /media/mckinsey/industries/retail/our\%20insights/perspe ctives\%20on\%20retail\%20and\%20consumer\%20goods\%20number\%208/perspectives -on-retail-and-consumer-goods_issue-8.pdf

[8] Grand prix EFFIE Awards 2020. Effie Ukraine. 2020. https://effie.org.ua/en/winners/

[9] Тата Кучер. Карантин виштовхнув ритейлерів у онлайн. Як METRO грає на цьому полі з випередженням. Forbes. 2020. https://forbes.ua/news/znayti-i-prodati05102020-215

[10] Manuel Castells. The Internet Galaxy: Reflections on the Internet, Business, and Society. Oxford: Oxford University Press, 2002. 292 p. 